\title{
Unicidade e Comunidade: A Recepção de M. STiRner em L'Homme Révolté de Albert Camus
}

\author{
José Luis Pérez
}

\begin{abstract}
RESUMO: O presente artigo pretender estudar a recepção da filosofia de Max Stirner por Albert Camus em L'Homme révolté, nomeadamente a partir da articulação entre dois conceitos centrais nos pensamentos de ambos os autores: revolta e revolução. Num momento conclusivo, e com base na leitura comparativa entretanto desenvolvida, é proposta uma aferição da validade das objecçôes feitas pelo ensaísta franco-argelino à filosofia stirneriana, em particular no que à questão da comunidade e unicidade diz respeito.
\end{abstract}

PALAVRAS-CHAVE: Camus. Stirner. Revolta. Revolução. Comunidade. Individualismo.

No livro dedicado à influência do pensamento de Max Stirner sobre o movimento existencialista francês do século passado, o historiador da Filosofia Henri Arvon qualificou Der Einzige und sein Eigentum, principal obra do autor alemão, como o "[...] primeiro esboço de o homem revoltado" (1954, p.6). Apesar de não aprofundar a declaração em Aux sources de l'existentialisme, é sem dúvida o escrito homonimo de Albert Camus o que o comentador francês tem em mente, ao ter sido ela proferida exactamente três anos após a publicação de L'Homme révolté.

O presente estudo visa clarificar o sentido da afiliação assim sugerida por Arvon, ou seja, discernir em que medida o pensamento camusiano foi determinado no essencial pelas perspectivas stirnerianas. E antecipando o que espero conseguir mostrar nas páginas que se seguem, diria que, se é inegável a partilha do que se poderia chamar um certo clima de pensamento, com a mesma evidência se impóe que esta proximidade especulativa não é de todo uma repetiçáo insensível, por parte do ensaísta de origem argelina, das principais ideias de Stirner. Pois, se é indiscutível que a filosofia de Camus surpreende na figura deste pensador alemão uma herança incontornável para o seu próprio projecto fundamental de compreensão do fenómeno da revolta na Modernidade ocidental, acaba também por se demarcar vigorosamente

${ }^{1}$ Centro de Filosofia da Universidade de Lisboa. Correio electrónico: jlsperez@gmail.com 
da proposta do irredutível individualismo encarnado na figura do Único, reconhecendo a dimensão genuinamente comunitária em que se inscrevem tanto as origens como as aspiraçôes do fenómeno em apreço.

\section{O HORIZONTE DA RECEPÇÁO CAMUSIANA}

Com vista a entender a hipotética ascendência das ideias desenvolvidas em Der Einzige und sein Eigentum sobre a meditação camusiana, importa referir preliminar e sucintamente o principal propósito atribuído por Camus a L'Homme révolté. Neste estudo, é prosseguida uma inquirição filosófica iniciada cerca de dez anos antes com Le Mythe de Sisyphe, destinada nas suas linhas fundamentais a determinar o estilo de vida mais fidedignamente condizente com a lúcida constatação da absurdidade da condição humana ${ }^{2}$. Sob a talvez inadvertida inspiração de um outro filósofo alemão largamente invocado e criticado em L'Homme révolté, Georg W. F. Hegel, Camus dá continuidade a essa meditação matricial, partindo agora da compreensão do que ele diz ser "a realidade do momento"3, e acabando por superar o individualismo decorrente daquela filosofia absurdista em proveito da consagraçáo de uma ideia de comunidade possibilitada pela própria análise da essência de revolta.

No que diz respeito a essa singularidade da realidade epocal em que se enquadram as meditaçóes de L'Homme révolté, Camus fá-la coincidir com a justificação ideológica da violência que encontra o seu terreno mais fértil nos contemporâneos regimes totalitários nazi e soviético, atribuindo a esta espécie de idiossincrasia temporal o nome de crime lógico ou crime racional ${ }^{4}$. Tendo em vista o derradeiro propósito de compreender as razóes de ser do paradoxo emergente de uma acção violentadora em nome da absoluta inocência com que os homens e mulheres ocidentais se debatem com uma realidade carenciada de fundamento último, o ensaio camusiano sobre a revolta procede a uma análise

\footnotetext{
2 "Se tenho como verdadeiro esse absurdo que regula as minhas relações com a vida, se me deixo penetrar por esse sentimento que me ganha ante os espectáculos do mundo, por essa clarividência que me impóe a procura de uma ciência, devo sacrificar tudo a estas certezas e olhar de frente, para poder mantê-las. Devo, sobretudo, regular por elas a minha conduta e persegui-las em todas as suas consequências" (CAMUS, 2007a, p. 31-32).

${ }^{3}$ Cf. CAMUS, 2003, p. 9. Isto de acordo com a definição de Filosofia avançada pelo filósofo de Iena no prefácio às suas Grundlinien der Philosophie des Rechts: "No que diz respeito ao indivíduo, cada um é, aliás, um filho do seu tempo; assim, a filosofia é também o seu tempo captado em pensamentos" (HEGEL, 1990, p. 198).

4 "Mas os campos de escravos sob o estandarte da liberdade, os massacres justificados pelo amor do homem ou pelo gosto de uma super-humanidade, perturbam, num sentido, o julgamento" (CAMUS, 2003, p. 10).
} 
selectiva das figuras do pensamento e acontecimentos históricos balizados entre os séculos XVIII e $\mathrm{XX}^{5}$ que apoia a hipótese, também ela com um cunho hegeliano, de uma lógica de desenvolvimento histórico que explicaria uma tal realidade paradoxal.

A redacção desta secular história do orgulho europeu, como o próprio autor a qualifica, e que mais não é do que um breviário do niilismo ocidental que alcança a sua encarnação última nas catástrofes sociopolíticas do século passado, é norteada pelo conceito basilar de revolta metafísica. Se a ideia de revolta não é, como reconhece Camus, inteiramente estranha à cultura helénica arcaica, em particular no que se refere à filantropia de Prometeu, o seu sentido propriamente metafísico só se manifesta plenamente na radical contestação da hegemonia da mundividência cristá no Ocidente, iniciada segundo o autor franco-argelino pelo marquês de Sade, e contemporânea da igualmente inédita ruptura encetada no campo político com a Revolução Francesa ${ }^{6}$.

Para Camus, esta revolta metafísica, movimento que leva um homem a insurgir-se contra a sua condição ${ }^{7}$, adquire assim o seu sentido mais próprio em referência directa à imagem de um Deus pessoal a quem precisamente se atribui a autoria da Criação e de uma revoltante condição humana fidedignamente representada pela imagem de quem se conhece injustificada e injustamente condenado à morte. No horizonte duma divindade moral estranha ao panteão grego, o cunho metafísico da revolta é dado pela absoluta inocência de que se reclama o insurgente perante a precária condição que lhe foi concedida ${ }^{8}$, protesto este que instaura na Modernidade uma marcada separação entre o humano e o divino que, contrariamente à mundividência grega, exclui terminantemente qualquer gradação entre os mesmos?.

\footnotetext{
${ }^{5}$ Para a justificação da orientação, limites e pretensôes do ensaio sobre a revolta, cf. CAMUS, 2003, p. 18. 6 "A teocracia foi atacada em 1789 no seu princípio e morta em 1793 na sua encarnação" (CAMUS, 2003, p. 147).

7 "A revolta metafísica é o movimento pelo qual um homem se insurge contra a sua condição e contra a criação inteira. É metafísica por contestar os fins do homem e da criação. O escravo protesta contra a situação que lhe criaram no interior do seu estado; o revoltado metafísico contra a condição que lhe criaram na sua condição de homem" (CAMUS, 2003, p. 35).

8 "Só a noçấo do deus pessoal, criador e portanto responsável por todas as coisas, pode dar um sentido ao protesto humano" (CAMUS, 2003, p. 41). O direito primário que o revoltado metafísico arvora em face de Deus traduz, para Camus, como ficou dito, a exigência de explicação e de justificação do sofrimento e da morte enquanto aspectos constitutivos da condição humana. Cf. CAMUS, 2003, p. 124-125.

9 "É que a revolta metafísica pressupốe uma panorâmica simplificada da criaçấo que os Gregos não podiam ter. Para eles náo havia, de um lado, os deuses e, do outro, os homens, mas degraus que iam
} 


\section{A InsURReiçấo CONTRa o divino}

Uma vez exposta a fisionomia fundamental do ensaio sobre a revolta, importa dizer que o indício mais rudimentar da sua proximidade com o pensamento de Stirner surge logo neste procedimento de análise histórica de fundo ao qual Camus recorre transversalmente em L'Homme révolté, em particular no referente ao processo de usurpação do trono outrora ocupado por Deus, que desde a inaugural insurreição metafísica de 1789 teria lavrado, segundo o autor, o destino cultural e político do Ocidente.

$\mathrm{Na}$ primeira parte de Der Einzige und sein Eigentum, intitulada "O Homem" [Der Mensch] e contraposta ao momento conclusivo, "Eu" [Ich], Stirner esboça, à semelhança de Camus no assinalado ensaio, as linhas gerais do suposto processo emancipatório do Homem face ao divino, em seguida demonstrando o carácter falacioso do mesmo, e assim reivindicando e justificando o programa individualista do Único [Einzige] e do seu egoísmo esclarecido. Como assinala Arvon (1954, p. 47), o ritmo binário da obra stirneriana reflecte dois momentos fundamentais, não só da reflexão proposta pelo autor, como da própria dinâmica do Eu com ela avançada, coincidindo um deles com o diagnóstico da alienação subsistente no referido processo de emancipação e o outro com a démarche de reapropriação afirmativa do Único.

Seguindo as pisadas do trabalho genético-crítico de Ludwig Feuerbach, com o qual se procurara reconduzir a essência da religiấo cristã a uma alienação da essência humana ${ }^{10}$, Stirner tornara patente, na assinalada secçâo inaugural do seu escrito, de que modo a particular reacção do autor de Das Wesen des Christentums, paralelamente a outros putativos desmascaramentos da origem demasiado humana do divino, acabara por redundar numa nova divinização que, em nada diferente quanto à sua origem, assentava no mais fundamental dos estranhamentos do Eu à luz da unicidade e irredutibilidade do mesmo a qualquer conceito ou ideia ${ }^{11}$. De acordo com Stirner, e sintetizando de algum

dos últimos aos primeiros. A ideia de inocência em oposição à de culpabilidade, a visão de uma história inteira resumida à luta do bem e do mal era-lhes totalmente alheia. No seu universo, há mais faltas do que que crimes; o único crime era o exagero" (CAMUS, 2003, p. 41).

10 "Pelo seu Deus conheces o homem e, vice-versa, pelo homem conheces o seu Deus; é a mesma coisa. O que para o homem é Deus, isso é o seu espírito, também a sua alma, e o que para o homem é o seu espírito, a sua alma, o seu coração, isso é o seu Deus: Deus é o interior revelado, o si-mesmo do homem expresso, a religiáo é o desvendamento festivo dos tesouros escondidos do homem, a confissão dos seus pensamentos mais íntimos, a proclamação pública dos seus segredos de amor" (FEUERBACH, 1994, p. 22-23).

${ }^{11}$ Para M. Stirner, a denúncia feuerbachiana da alienaçấo religiosa desembocaria, apesar de tudo, na transposição do carácter sagrado do divino para o humano, o que redundaria numa incapacidade 
modo o conteúdo programático da sua obra, o fundamental seria ver de que modo "[...] as mais recentes revoltas contra Deus não são mais do que os últimos esforços da teologia, ou seja, insurreiçôes teológicas” (2004, p. 30).

A expressão com a qual Stirner condensa este esforço de desmistificação do divino é bastante sugestiva: o filósofo alemão designa aqueles que o perpetraram como autênticos titâs, aludindo assim à titanomaquia grega em que é relatada a guerra daquelas figuras mitológicas reunidas a dado momento sob o comando de Cronos contra a hegemonia olímpica de Zeus ${ }^{12}$. Para Stirner, a acção à qual assim se entregaram os que tomaram de assalto o céu "[...] limita-se a isto: revolver desde o fundo as instituiçốes humanas, para criar outras, melhores, sobre o terreno limpo, corromper toda a moral para pôr no seu lugar uma outra, nova e melhor" (2004, p. 61).

De acordo com o autor alemão, mais do que abolir por completo uma ordem plenamente reconhecida na sua falsa supremacia, o que esses audazes escaladores do céu fizeram foi levar a cabo um processo de reforma, ignorando a necessidade de uma verdadeira criaçáo precedida por um processo fundamental de nadificação. Para Stirner, essas reformas traduzir-se-iam necessariamente na configuração de novos sucedâneos de uma ideia que, apesar de tudo, acabara por permanecer intacta no seu sentido profundo, resumindo ela o gesto mais acabado da alienação individual. Hegel, Feuerbach, os teóricos do liberalismo político, e finalmente os comunistas, acabariam por desconhecer o que realmente constitui a essência primitiva do divino e que é o elemento justificador do próprio conceito de reforma, a saber: a dimensão do sagrado.

Se voltarmos agora a nossa atenção para Camus, surpreendemos exactamente a mesma denúncia de uma perpetuação do divino em toda a sua sacralidade por parte das atitudes revoltadas modernas e contemporâneas. A proximidade com a perspectiva stirneriana acima exposta é de tal forma

de compreensão da subsistência da verdadeira alienação: a do indivíduo e sua unicidade. "Depois da destruição da fé, Feuerbach sonha com a entrada na baía pretensamente segura do amor. 'A lei suprema e primeira deve ser o amor do homem pelo homem. Homo homini deus est - é este o princípio prático superior, é este o ponto de viragem da história universal.' Mas, na verdade, só o 'Deus' mudou, o amor ficou; de um lado, o amor ao Deus sobre-humano, do outro, o amor ao Deus humano, ao homo enquanto deus. Ou seja, o homem é para mim... sagrado. E tudo aquilo que é 'verdadeiramente humano’ é para mim... sagrado!” (STIRNER, 2004, p. 52).

12 "Na laboriosa luta da raça mongol, os homens tinham construído um céu quando os descendentes da estirpe caucásica, no que eles é ainda coloraçấo mongol e tem a ver com o céu, se propuseram a tarefa oposta, a tarefa de deitar abaixo o céu da moral, uma obra de titâs" (STIRNER, 2004, p. 61). 
assinalável que a própria metáfora de um assalto aos céus surge no seu ensaio sobre a revolta:

\begin{abstract}
A revolta contra a condição assume o aspecto de uma expedição desmesurada contra o céu para dele trazer um rei prisioneiro do qual proclamará a queda, a que se seguirá a condenação à morte. A rebelião humana termina em revolução metafísica [...] [e] uma vez derrubado o trono de Deus, o rebelde reconhecerá que essa justiça, essa ordem, essa unidade que ele em vão procura na sua condição, acaba agora por ser criada por suas próprias máos e, por esse facto, se justificará assim a queda divina. Começará então um esforço desesperado para fundar, por meio do crime, se tal for necessário, o império dos homens. (CAMUS, 2003, p. 37).
\end{abstract}

Se este excerto camusiano tem a virtude de atestar a vizinhança da revolta metafísica com a concepção stirneriana de uma insurreição contra o divino, importa salientar que do mesmo passo se inaugura nele, porém, o horizonte mais original do pensamento do autor franco-argelino. Com efeito, o desfasamento temporal que o separa de Stirner permite-lhe um alargamento do espectro de análise dos resíduos divinos metamorfoseados em outras tantas abstracçôes. Pois, se a apreciação histórica de Stirner, quanto ao impacto dessa revolta, se cinge à Revolução Francesa e aos seus ecos mais imediatos, Camus está em posição de assistir além do mais à consolidação histórica de novas efígies do divino que negam, no seu carácter abstracto, a irredutibilidade do indivíduo concreto também exaltada pelo filósofo alemão.

Ora, aos olhos de Camus, o século XX daria precisamente conta da concretização do antigo sonho platónico de uma sociedade governada por filósofos, o mesmo é dizer da submissão da política à unilateralidade de abstracçóes tão variadas nas suas formas como homicidas nas suas consequências, tendo em conta em particular o ideal nazi da sobrehumanidade de inspiração nietzscheana e a aspiração marxista à definitiva sociedade sem classes. As ressonâncias histórico-políticas dessa grande cruzada moderna contra Deus difundem-se, segundo Camus, sob a forma de processos revolucionários que partilham uma mesma justificação filosófica da violência em face da resistência concreta de facções emergentes. Mas, se a novidade da reflexão camusiana parece residir nesse alargamento do campo de estudo das abstracçôes dinamizadoras da história dos homens, assim como na denúncia das mesmas como consequências nefastas de uma exigência originária de mudar e organizar um mundo sem Deus e exclusivamente com as máos de homens, a verdade é que, pese embora o desfasamento temporal de que 
beneficia o estudo camusiano sobre a revolta, o grande acontecimento da Modernidade que foi a Revolução Francesa permitira já a Stirner compreender na sua essencialidade um tal fatídico dinamismo de permuta de autoridade, considerado como inerente a todo e qualquer processo revolucionário.

\section{REVOLUÇÁO E REVOLTA}

De acordo com Stirner, o sopro original de qualquer revolução [Revolution] coincidiria no fundo com um espírito de simples melhoramento, no sentido preciso de uma reforma que culmina impreterivelmente na instauração de um novo poder erguido acima dos indivíduos e, por isso mesmo, negador da peculiaridade ou ser-próprio [Eigenheit] dos mesmos. À semelhança da reforma protestante, com a qual se afirma a passagem da exterioridade da autoridade divina para a sua interiorização na figura da consciência moral individual, sem que por isso mesmo desapareça o princípio estranho ao $\mathrm{Eu}$, para Stirner (2004, p. 92), a Revolução Francesa "[...] não foi dirigida contra $a$ ordem estabelecida, mas contra esta ordem estabelecida, contra um determinado estado de coisas. Acabou com este soberano, mas não com os soberanos [...]". Ainda segundo Stirner, o motivo que desvirtua esta e qualquer outra forma de revolução coincide com o facto de o visado pela prática revolucionária ser não tanto uma autoridade assumida enquanto princípio opressor e determinante do indivíduo, mas simplesmente a roupagem com a qual a mesma se singulariza em cada caso. Ainda relativamente a essa insurreição moderna, salienta Stirner que o processo revolucionário

[...] assestou a suas armas sobre tudo o que vinha da "graça de Deus", por exemplo contra o direito divino, cujo lugar foi ocupado por um direito humano mais fortalecido [e, desta forma,] àquilo que é concedido pela graça de Deus contrapóe-se aquilo que é derivado "da essência do homem". (STIRNER, 2004, p. 195).

Ora, na linha do raciocínio stirneriano, a Revolução Francesa acabara por obedecer à dinâmica própria de todo e qualquer movimento revolucionário, não só por efectivar uma alteração que, apesar da radicalidade dos meios e ambiçóes associados, está sempre orientada para a consagraçáo de um outro princípio inquestionável, como por além do mais desembocar num processo reactivo ${ }^{13}$.

\footnotetext{
13 "Se a revolução degenerou em reacção, isso só veio revelar o que a revolução realmente era. De facto, toda a aspiração acaba em reacção quando intervém a reflexão sensata, e só avança com ímpeto na sua acção inicial enquanto é inebriamento, 'insensatez'. 'Sensatez' será sempre o lema da reacção, porque a
} 
Se a Revolução Francesa se afirma à primeira vista como uma incomparável conquista histórica, ao ter apelado para uma concórdia interpessoal sem qualquer intermediação sobrenatural, permaneceu com ela ilesa, apesar de tudo, a verdadeira opressão, aquela que atenta contra o indivíduo na sua unicidade e irredutibilidade a qualquer ideia ou abstracção. Declara Stirner:

Os direitos do homem, a obra mais cara à Revolução, têm o sentido de que o homem em mim me dá o direito de ter isto e aquilo, [mas que] eu, como indivíduo, este homem concreto, não tenho direitos: o homem tem todos os direitos e é ele que mos concede a mim. [Por conseguinte,] enquanto homem, posso, assim, ter direitos; como, porém, eu sou mais que homem, sou um homem particular, esses direitos podem ser-me negados precisamente a mim, a este indivíduo particular. (STIRNER, 2004, p. 247).

Esta crítica stirneriana da ideia de revolução assenta num mais essencial projecto de revalorização do indivíduo, em muito motivado pela cada vez mais apregoada submissão do indivíduo ao Estado, que Hegel inaugurara e que fora reafirmada por alguns dos seus discípulos. O individualismo de que faz apologia o pensamento stirneriano está patente na crítica da ideia de revolução a partir da sua contraposição à ideia de revolta [Empörung], e esta contraposição delineia o horizonte mais fértil para a compreensão da verdadeira amplitude do projecto stirneriano de reafirmação do indivíduo único.

Enquanto inversão das condiçôes ou do estado das coisas existentes na sociedade, a revolução afigura-se, segundo Stirner, como um acto político ou social que visa o estabelecimento de novas instituiçóes, mais aptas do que as antigas para satisfazer a reivindicação contida nesse mesmo processo revolucionário. Mas, para Stirner, se

[...] a revolta tem [...] na transformação do estado de coisas uma consequência necessária, [...] não parte dela, [mas] da insatisfação do homem consigo mesmo, [afigurando-se assim] uma rebelião do indivíduo, um emergir sem pensar nas instituiçôes que daí possam sair. [Por outras palavras, se] a revolução tinha por objectivo criar novas instituiçóes, a revolta leva a que não nos deixemos organizar, organizando-nos antes nós próprios; não deposita grandes esperanças nas “instituições”. (STIRNER, 2004, p. 248).

sensatez póe limites e liberta aquilo que verdadeiramente se deseja do 'desregramento' e dos 'excessos' do início" (STIRNER, 2004, p. 91). 
Surpreendemos nesta última afirmação todo o conteúdo programático do escrito Die Einzige und sein Eigentum. Sendo o seu propósito primordial o de aclarar a radical autonomia do indivíduo enquanto ponto de apoio e de legitimação de toda e qualquer ideia ou valor, é compreensível que a revolta constitua o mais originário dos seus dinamismos, por se afirmar ela simultaneamente como negação do poder alheio e posição do ser-próprio do indivíduo. Se a revolução ostenta um carácter social, sendo o indivíduo valorizado nela somente em função do estabelecimento de novas instituições que acabarão por se colocar acima do mesmo e às quais ele deverá prestar obediência, um movimento diverso é assinalado com a revolta. De acordo com Stirner, a revolta não é uma

[...] luta contra o status quo, uma vez que, desde que ela floresça, o status quo entra por si próprio em derrocada, [mas é] [...] apenas um meio activo que permite ao eu emancipar-se da situação vigente. [...] A minha intenção [com a revolta] não é a de derrubar a situação vigente, mas a de me elevar acima dela, a minha intenção e a minha acção não são de ordem política ou social, mas, orientadas como estão para mim e a minha singularidade própria, de ordem egoista. (STIRNER, 2004, p. 248).

Importa determo-nos neste conceito, egoísmo [Egoismus], a fim de revelar o sentido estruturante que o mesmo possui na economia do pensamento do Único. Lei fundamental do universo stirneriano, considerado como inimigo mortal pela religião e pelos seus diversos sucedâneos filosóficos e políticos, o egoísmo configura, para o autor alemão, o dinamismo mais elementar da vida individual. Com efeito, o suposto desinteresse de uma dada acção reconhecida como altruísta ou caridosa acaba sempre por dissimular, para Stirner, uma incontornável referência primitiva ao indivíduo e ao seu poder. E é a percepção ou não percepção desta mesma inescapável referência a si mesmo em toda e qualquer acção individual o que acaba por diferenciar o que Stirner entende ser o egoísta voluntário do egoísta involuntário ${ }^{14}$, sendo

\footnotetext{
14 "O sagrado só existe para o egoísta que não se reconhece, para o egoísta involuntário, para aquele que se coloca sempre em primeiro lugar sem, no entanto, se considerar o ser supremo, que só serve a si próprio e ao mesmo tempo pensa servir a um ser superior, que náo conhece nada acima de si e todavia anseia por algo de superior, em suma, para o egoísta que náo quer ser egoísta e se rebaixa, ou seja, combate o seu egoísmo, mas ao mesmo tempo só se rebaixa 'para poder ser elevado' que o mesmo é dizer, para satisfazer o seu egoísmo. Como quer deixar de ser egoísta, procura no céu e na terra seres superiores a quem servir e a quem se sacrificar; mas, por mais que se sacuda e se mortifique, ao fim e ao cabo tudo o que faz fá-lo somente por interesse pessoal e o seu famigerado egoísmo nunca o abandona. Por isso lhe chamo o egoísta involuntário" (STIRNER, 2004, p. 37).
} 
o cristão um exemplo significativo deste último tipo. De acordo com Stirner, o Eu consciente do seu egoísmo assume ao mesmo tempo a sua condição de juiz absoluto, ou seja, legitimador de toda e qualquer ideia ou acção: “[...] se eu tenho ou não razão, o único juiz que o decide sou eu próprio. Os outros podem apenas julgar e condenar dizendo se aceitam ou não o meu direito, e se ele é também um direito para eles" (STIRNER, 2004, p. 149). Com esta afirmação, e antecedendo uma ideia que será reavivada pelo existencialismo contemporâneo, Stirner declara que o Eu é justamente esse nada criador do qual depende a todo momento a consistência e congruência das ideias e dos valores. Atentemos na seguinte passagem:

Qualquer juízo que eu faça sobre um objecto é uma criatura da minha vontade [...]. Todos os predicados dos objectos são afirmaçóes minhas, juízos meus, criaturas minhas. Se eles quiserem libertar-se de mim e ganhar autonomia, ou mesmo impor-se-me, o que tenho a fazer é fazê-las regressar ao seu nada, isto é, a mim, seu criador. Deus, Cristo, a Santíssima Trindade, a moralidade, o bem, etc., são criaturas destas, sobre as quais sou livre de afirmar, tanto que elas são verdades, como que elas são ilusôes. Do mesmo modo que quis e decretei a sua existência, também posso querer a sua náo existência; não posso permitir que elas me ultrapassem, não posso ter a fraqueza de deixar que se transformem em algo de "absoluto", o que levaria a que elas se eternizassem e se furtassem ao meu poder e ao meu controlo. Com isso, cederia ao princípio de estabilidade, o verdadeiro princípio vital da religiáo, que se propôe criar "santuários intocáveis", "verdades eternas", em suma, "objectos sagrados", e roubar-te aquilo que te épróprio. (STIRNER, 2004, p. 264).

A categoria do sagrado, transversal a todos os sucedâneos do divino, indicia, como ficou frisado, a alienação mais fundamental desse poder originário do $\mathrm{Eu}$, a partir do momento em que as ideias e valores cuja existência e sentido dependem do consentimento deste último se tornam ideias fixas [fixen Ideen], abstracçóes que se furtaram à hegemonia e ao controlo do nada criador ao qual devem toda a sua validade e efectividade ${ }^{15}$. O sagrado caracteriza-se, na óptica

\footnotetext{
15 "Cuidado, rapaz, tens a cabeça cheia de fantasmas, tens obsessōes a mais! Imaginas coisas grandiosas e inventas todo um mundo de deuses à tua disposição, um reino de espíritos que te chama, um ideal que te acena. Tens uma ideia fixa! E não penses que estou a brincar ou a falar por metáforas quando considero os homens presos a esta ideia superior (de facto, quase toda a humanidade, porque a maior parte é deste tipo) como verdadeiros loucos, loucos de manicómio. O que é afinal isso de uma 'ideia fixa'? É uma ideia à qual uma pessoa se subjugou. Se reconhecerdes nessa ideia fixa um sinal de loucura, meteis o escravo dela num manicómio. Mas não serão também 'ideias fixas' a verdade da fé de que se não duvida, a majestade - por exemplo, do povo - em que não se pode tocar (e quem o fizer comete
} 
stirneriana, por ostentar precisamente uma dimensão essencial de estranheza, por ser um espaço no qual o Eu deixa literalmente de se sentir chez soi, em sua casa ${ }^{16}$. Ora, é exactamente esta condição de criador-credor o que o Eu deve reassumir plenamente como modo de afirmação da sua peculiaridade enquanto poder simultaneamente negador e criador.

No que diz respeito a Camus, a afinidade entre as suas reflexóes em torno da revolta e as stirnerianas é bem manifesta na marcada distinção a que ele também procede entre revolta [révolte] e revolução [révolution]. A primeira é caracterizada por Camus como um testemunho sem coerência, no sentido em que não implica o suporte teórico ou ideológico essencial à revoluçấo que começa precisamente com a consagração de uma ideia, à qual se procura subsequentemente moldar a realidade concreta ${ }^{17}$. Sobressai com efeito uma afinidade entre a visão camusiana e a stirneriana, nomeadamente no que se refere ao facto de a revolta, contrariamente à revolução, não ter como finalidade a sagração de uma qualquer abstracção que se sobrepôe aos próprios indivíduos que a protagonizam. Além do mais, entendida no seu carácter cumulativo, a revolta em Camus não deixa de evocar a ideia stirneriana da associação de egoistas [Verein von Egoisten], o modelo de relação inter-individual proposto pelo autor alemão contra todo o tipo de relação mediada por um terceiro elemento encarnado nas referidas ideias fixas, o qual pairaria acima dos indivíduos e ordenaria o seu comércio concreto. Contrariamente à noção de sociedade ou de Estado, a associação de egoístas caracterizar-se-ia justamente por ser uma reuniáo voluntariamente aceite pelos indivíduos que nela concertariam as suas acçóes com vista a um determinado objectivo por eles ambicionado, e sujeitando essa mesma reunião à duração temporal dos interesses assim declarados.

crime de lesa-majestade), a virtude, contra a qual o censor não deixará passar nem uma palavra, para que a moralidade permaneça intacta, etc.?” (STIRNER, 2004, pp. 41-42).

16 “A estranheza é a marca do 'sagrado'. Em tudo o que é sagrado há qualquer coisa de 'inquietante', isto é, estranho, que não nos é familiar e não nos aquieta. Aquilo que é sagado para mim, não é meu [...]" (STIRNER, 2004, p. 37).

17 "Originariamente, o movimento de revolta em breve se extingue. Não passa de um testemunho sem coerência. A revolução, pelo contrário, começa a partir da ideia. Ela é precisamente a inserção da ideia na experiência histórica quando a revolta não passa do movimento que conduz da experiência individual à ideia” (CAMUS, 2003, p. 132). 


\section{A CRÍtica do ÚNICO}

Apesar da contiguidade existente em determinados aspectos, o certo é que a posição de Camus relativamente ao individualismo stirneriano que tem vindo a ser exposto é-nos apresentada em L'Homme révolté num tom marcadamente crítico, e que alguns dos argumentos avançados nessa mesma crítica não deixam de se apresentar como polémicos.

Um primeiro ponto tem a ver com a caracterização da posição stirneriana, por parte de Camus, como máxima expressão de uma atitude de blasfémia que, iniciada com Sade, acabaria por conduzir ao ateísmo radical de diversos autores contemporâneos. Ora, é evidente que esta atitude implica um reconhecimento da existência de Deus, assumindo-se nesse sentido como uma provocação ou desafio ao mesmo, mais do que como uma sua negação. A existir realmente uma provocação na reflexão de Stirner, a verdade é que ela não se dirige tanto contra a figura do Deus pessoal, mas antes contra a ideia mais originária do sagrado, a qual ainda se repercutiria na Modernidade como eco do derradeiro suspiro divino. O reconhecimento stirneriano da ausência de Deus é claro na epígrafe que inicia a segunda secção do seu Der Einzige und sein Eigentum ${ }^{18}$, pelo que considerar este autor como simples blasfemo equivaleria a ignorar toda a complexidade da sua reflexáo em torno do Único, não se reconhecendo a categoria de sagrado justamente como produto e criatura desse nada criador que o indivíduo é, ou seja, como sua propriedade [Eigentum], por isso mesmo sujeita ao seu poder originário de legitimação. Em suma, o conceito de blasfémia implica a ratificação, por parte do blasfemador, de uma consistência fundamental de Deus que é independente daquele que comete a injúria, a anterioridade de direito da instância divina relativamente à instância humana.

Mas o carácter verdadeiramente controverso da leitura camusiana de Stirner parece-me residir na qualificação que Camus faz do relacionamento interindividual, no pensamento do autor alemão, como estritamente conflituoso. Certamente que o individualismo entrevisto por Camus na tematização

\footnotetext{
18 “No início da Idade Moderna está o 'homem-deus'. Na sua fase final desaparecerá apenas o deus do homem-deus? E pode o homem-deus morrer realmente se apenas morrer o deus nele? Não se pensou nesta questáo, e julgou-se que um processo tinha chegado ao fim quando a obra das Luzes, a superação de Deus, foi levada a uma vitória final nos nossos dias. Náo se reparou que o homem tinha matado o deus para se tornar 'o único deus nas alturas'. O além fora de nós, aliás, foi varrido, e com isso consumou-se a grande tarefa das Luzes. Mas o além em nós tornou-se um novo céu e apela para nós no sentido de novo assalto aos céus: o deus teve de dar lugar, não a nós, mas... ao homem. Como podeis vós crer que o homem-deus morreu, se não morreu ainda nele, para além do deus, também o homem?” (STIRNER, 2004, p. 125).
} 
stineriana do Único não pode deixar de lembrar esse bom niilismo que ele mesmo defendera, no ciclo do Absurdo da sua obra, e cujo ponto de partida consistia precisamente na ausência de um qualquer princípio ou finalidade a partir do qual se pudesse julgar em absoluto, como boa ou má, uma determinada acção individual. Com efeito, a caracterização do homem absurdo, presente em Le Mythe de Sisyphe, como criatura determinada pela absurdidade da existência própria, encarcerada nos muros de uma morte sempre iminente, assemelhase em muito à noção do Único elevado por Stirner acima de qualquer tipo de poder exterior e cuja intenção motivadora é a satisfação própria. Porém, a evolução da obra de Camus deu-se no sentido de uma denúncia da inviabilidade desse mesmo bom niilismo vertido na exclusiva valorização da vida própria e na consequente rejeição do suicídio. Ora, a exigência subjacente a essa evolução consistia no reconhecimento da impossibilidade de falar de um niilismo que seria, por assim dizer, a meias, dito de outro modo, que da afirmação do valor absoluto da vida própria não pode decorrer uma indiferença face ao valor da vida dos outros seres que partilham uma mesma condição. Crítico das suas exploraçóes passadas, Camus traz assim à discussão o pensamento de Stirner sob a acusação de adoptar ele a máxima segundo a qual viver é transgredir ${ }^{19}$ ou, por outras palavras, abolir a cada instante todas as barreiras com as quais a vontade do Único se depara na sua caminhada existencial. Na verdade, teria sido justamente essa a conclusão à qual chegara o raciocínio absurdo apresentado no ensaio de 1942, o qual consagrara, não tanto a incitação ao homicídio, mas uma natural indiferença perante $\mathrm{o}$ mesmo.

Podemos afirmar, portanto, que a leitura camusiana do pensamento de Stirner acaba por privilegiar aqueles aspectos que denunciam, mesmo que justificadamente, a "alegria sombria", a "satisfação amarga no caos", conforme as palavras camusianas, próprias de um indivíduo indizível e inclassificável que proclama orgulhosamente: "Eu sou a minha causa, eu que, como Deus, sou o nada de tudo o resto, eu que sou o meu tudo, eu que sou o único" (STIRNER, 2004, p. 10). À imagem e semelhança de Deus, dir-nos-ia Camus, o Eu de Stirner ergue-se enquanto legítimo detentor do poder de dar morte aos outros, sem que exista um qualquer valor acima dele que o inscreva numa comunidade fundada na absoluta interdição de matar. Contudo, ainda que não se possa negar a legitimidade desta leitura camusiana, o certo é que Der Einzige und sein Eigentum não configura um Evangelho com aspiraçóes

19 "Deixou de haver crimes e faltas: portanto, igualmente se acabaram os pecadores. Somos todos perfeitos. Uma vez que todo o eu é, em si mesmo, essencialmente criminoso para com o Estado e para com o povo, saibamos reconhecer que viver é transgredir" (CAMUS, 2003, p. 83). 
à conversão, mas antes uma espécie de intransmissivel discurso do método com o qual Stirner, mais do que concluir na necessidade de incitar à guerra de todos contra todos, procura desmontar os preconceitos pelos quais o $\mathrm{Eu}-\mathrm{ou}$ melhor, Ele, o indizível - oculta a si mesmo essa sua lei vital que é o egoísmo.

À semelhança do que outros já haviam feito, Camus (2003, p. 83) assinalava que o Eu stirneriano, "[...] alçado contra todas as abstracçôes, [se tinha] tornado ele mesmo abstracto e inominável à custa de ser sequestrado e cortado das suas raízes". Porém, esta descrição parece não ser fiel ao pensamento stirneriano, se pensarmos que, a haver uma luta contínua do autor alemão, ela foi levada a cabo contra a projecção de ideias fixas ou absolutas. Em última instância, sublinhando a inadequação da descrição camusiana, poderíamos mesmo salientar a própria absurdidade, em Stirner, de uma qualquer ideia de um dever matar.

Quanto à crítica da indiferença do Único stirneriano em face do crime, nada podemos afirmar em sentido oposto, pois o quadro reflexivo proposto pelo autor alemão possibilita efectivamente uma tal visão. Ao não haver autoridade superior independente da aprovação do $\mathrm{Eu}$, a legitimidade de uma qualquer sua acção dependerá de facto do único direito existente: o seu direito. Todavia, a indiferença diante do homicídio e a ausência de qualquer laço comunitário com os outros homens são coisas distintas. A afirmação de Camus (2003, p. 83) segundo a qual "[...] decretar a legitimidade do homicídio é decretar a mobilização e a guerra dos únicos” oculta, a meu ver, o lado marcadamente positivo e criador do pensamento comunitário stirneriano, que não o reduz à mera e cega exaltação da primazia da destruição ou do conflito. Numa passagem muito elucidativa, Stirner declara:

Também amo os homens, e não apenas alguns, mas cada um. Mas amo-os com a consciência do egoísmo; amo-os porque o amor me faz feliz, amo porque amar é a minha condição natural, porque me agrada. Mas não conheço um "mandamento do amor". (STIRNER, 2004, p. 229).

\section{NOTA CONCLUSIVA: PARA UMA UNICIDADE COMUM}

Criticar a ideia de comunidade na obra de Stirner não pode consistir, a meu ver, na simples denúncia da ausência de todo o tipo de laço com o outro que não o de conflito. Com efeito, a anterior passagem mostra claramente que a relação com a alteridade pode assumir um perfil construtivo ou criador. A única salvaguarda imposta por Stirner é a de que essa relação amorosa, 
caso queira preservar verdadeiramente a peculiaridade do $\mathrm{Eu}$, deve ser sua propriedade, isto é, consentida pelo seu egoísmo como algo que lhe interessa, logo não ordenada a partir de uma qualquer ideia fixa como, por exemplo, a de um dever de amar ou o de respeitar.

$\mathrm{Na}$ verdade, o que fica impossibilitado com esta perspectiva é simplesmente a atribuição de um carácter universal a esse amor aos homens, sendo conservada toda a determinação e concretude da relação comunitária, assim como toda a relatividade da mesma que, bem vistas as coisas, é o seu elemento matricial. Neste sentido, a imagem avançada por Camus de um Único stirneriano satisfeito e sorridente sobre as ruínas do mundo parece distorcer significativamente o que se diria ser certamente um pensamento solipsista, mas que acaba inevitavelmente por sê-lo de forma exclusiva no plano teórico.

À guisa de conclusão, diria que uma possível crítica à visão stirneriana da comunidade, a partir do pensamento camusiano, surgiria de uma forma menos controversa destacando o não-reconhecimento, por parte do filósofo alemão, de qualquer tipo de relaçáo ou laço entre os homens que pudesse ser dito autenticamente absoluto. Se é possível assumir como válida a afirmação de Stirner, segundo a qual, do ponto de vista do Eu que assume a sua peculiaridade, não existe qualquer tipo de dívida definitiva para com o outro, isto é, qualquer forma de relaçáo irrevogável que não seja objecto de criação contínua por parte do indivíduo considerado na sua unicidade, e se a própria ideia de uma fraternidade humana também pode ser posta em causa pelo juiz indigitado para suspender legitimamente a existência de qualquer valor, certo é que existe uma inquestionável ligação que, englobando todos os indivíduos, os mantém ainda assim paradoxalmente separados numa unicidade determinada pelo único absoluto dado a conhecer aos homens que é a morte. Com efeito, é com esta ideia de solidariedade em face de uma condiçáo mortal ${ }^{20}$ - uma solidariedade que não é nem pode ser criação ou objecto de suspensão definitiva por parte do Eu - que a própria unicidade do Único revela ser, no seu fundo, uma peculiaridade partilhada ou algo como um singular universal.

Se é verdade, como sugere Arvon, que o pensamento de Stirner acabou por influenciar as chamadas filosofias da existência do século XX,

${ }^{20}$ Como bem sugere a imagem oferecida por Pascal nos seus Pensamentos, tấo admirados por Camus: "Qu'on s'imagine un nombre d'hommes dans les chaînes, et tous condamnés à la mort, dont les uns étant chaque jour égorgés à la vue des autres, ceux qui restent voient leur propre condition dans celle de leurs semblables, et, se regardant l'un l'autre avec douleur et sans espérance, attendent leur tour!" (PASCAL 1977, fr. 405). 
nomeadamente através do apelo à autenticidade, à ideia de um Eu enquanto nada criador, a esse projecto sempre em aberto, náo deixa de ser menos certo que foram essas mesmas filosofias, e entre elas seguramente a de Camus, as que procuraram superar justamente o radical solipsismo stirneriano, conciliando a essencial componente comunitária com a irredutibilidade do indivíduo através da ideia de um parentesco fundamental de destino. O que faz todo o sentido, se dissermos, com o autor de L'Homme révolté: "A morte para todos, mas para cada um a sua morte" (CAMUS, 2007b, p. 46).

PÉREZ, J. L. Uniqueness and community: On the reception of Max Stirner in Albert Camus' The Rebel. Trans/Form/Ação, Marília, v. 36, n. 3, p. 53-68, Set./Dez., 2013.

\begin{abstract}
This paper addresses the reception of Max Stirner's philosophy by Albert Camus in his book The Rebel. A comparative reading of the views of the authors is developed, specifically through the articulation of two central concepts in the thought of both men - revolt and revolution. We evaluate of the validity of the objections presented by Camus to Stirner's philosophy, with a focus on the issues surrounding the concepts of community and uniqueness.
\end{abstract}

KEYWORDS: Camus. Stirner. Revolt. Revolution. Community. Individualism.

\title{
REFERÊNCIAS
}

ARVON, Henri. Aux sources de l'existentialisme: Max Stirner. Paris : P.U.F, 1954.

CAMUS, Albert. O Mito de Sísifo. Tradução de Urbano Tavares Rodrigues. Lisboa: Livros do Brasil, 2007a.

. O Avesso e o Direito. Tradução de Sousa Victorino. Lisboa: Livros do Brasil, 2007b.

. O Homem Revoltado. Tradução de Virgínia Motta. Lisboa: Livros do Brasil, 2003.

FEUERBACH, Ludwig. A Essência do Cristianismo. Tradução de Adriana Veríssimo Serrão. Lisboa: Fundação Calouste Gulbenkian, 1994.

HEGEL, G. W. F. Prefácios. Tradução de Manuel José do Carmo Ferreira. Lisboa: IN-CM, 1990.

PASCAL, Blaise. Pensées. Edição de Michel Le Guern. Paris: Gallimard, 1977.

STIRNER, Max. O Único e a sua Propriedade. Tradução de João Barrento. Lisboa: Antígona, 2004.

Recebido em: 21.11.2012

Aceito em: 19.03.2013 